\title{
Population Dynamics of Pseudevadne tergestina (Branchiopoda: Onychopoda) in Guanabara Bay, Brazil
}

\author{
Andrea Marazzo and Jean Louis Valentin ${ }^{*}$ \\ Departamento de Biologia Marinha; Instituto de Biologia; Universidade Federal do Rio de Janeiro; CCS; Bl. A; \\ jlv@biologia.ufrj.br; 21949-900; Rio de Janeiro - RJ - Brazil
}

\begin{abstract}
Populations of Pseudevadne tergestina were studied in Guanabara Bay, southeastern Brazil, to assess temporal variations in density and population dynamics. Data on temperature, salinity and zooplankton samples were taken from the superficial water of a fixed station, every 3 - 4 days, from February 2 through August 1, 2000. The highest abundance of this species was observed in March, when densities varied widely, from 20 to $600 \mathrm{ind}^{-3} \mathrm{~m}^{-3}$. Population parameters were calculated, such as birth rate (from 0.25 to 0.90 ind. $^{-1}$.day ${ }^{-1}$ ), growth rate (from -1.30 to 2.09 day ${ }^{-1}$ ) and death rate ( from -1.6 to 1.9 day $^{-1}$ ) Start of population could be attributed to the increase of temperature and to the hatching of resting eggs. The population collapsed in fall-winter, as result from the combined effects of different factors: decrease of water temperature (from $27^{\circ} \mathrm{C}$ to $21^{\circ} \mathrm{C}$ ) influencing egg development time (from 2.27 to 3.28 days); predation pressure by chaetognaths (Max. $100 \mathrm{ind} . \mathrm{m}^{-3}$ ) and switch of population from parthenogenic to sexual reproduction. Horizontal transport of water by tidal currents contributed partially to the reduction of population density.
\end{abstract}

Key words: Zooplankton, Cladocera, population parameters, temporal distribution, Guanabara bay, Brazil

\section{INTRODUCTION}

Pseudevadne tergestina (Claus 1877) is a seasonally abundant and widely distributed cladoceran in marine environments. It is an epizooplankter that occurs mainly in surface waters of coastal and embayment regions (Egloff et al., 1997). Although it is generally viewed as a secondary constituent of marine zooplankton, ranking much below copepods in population density, at times it comprises a significant fraction of the mesozooplanktonic community. When abundant, it may be an important item in the diet of planktivorous fish and zooplankton predators such as chaetognaths and ctenophores (Fofonoff,
1994). In such cases this marine cladoceran, together with other species such as Penilia avirostris and Pleopis polyphemoides, possibly play an important role in marine organic matter production. $P$. tergestina can rapidly reach high population densities by the strategy of parthenogenic reproduction accelerated by paedogenesis, namely the development of parthenogenic eggs in the brood chambers of embryos before the latter are released from their parent. This is a common phenomenon in podonids (Egloff et al., 1997).

Annual cycles of abundance have been recorded for many populations of marine cladocerans, including $P$. tergestina. Most reports are from cold and temperate oceans, where these animals

\footnotetext{
Author for correspondence
} 
generally occur in the warmer waters during the spring - summer period, e.g., in the Baltic (Vourinen and Ranta, 1987), the west coast of Sweden (Eriksson, 1974), the Mediterranean (Thiriot, 1972), the North Pacific (Uye, 1982), the Inland Sea of Japan (Onbé, 1985), and Narragansett Bay (Fofonoff, 1994). There are few studies on marine cladocerans in tropical regions. Along the Brazilian coast, $P$. tergestina was recorded by Resgalla Jr. and Montú (1993) on the southern continental shelf, and by Valentin et al. (1987) in the Cabo Frio area $\left(23^{\circ} \mathrm{S}\right)$ where it was affected by coastal upwelling. Alecrim (2000) and Marazzo and Valentin (2001) found this species in Guanabara Bay, Rio de Janeiro.

The objective of the present investigation was to study the density variations of $P$. tergestina in Guanabara Bay, including some aspects of population dynamics such as birth, growth, and mortality rates; fecundity of parthenogenic females; and the shift from a parthenogenic to a gamogenic reproductive strategy.

\section{STUDY AREA}

Guanabara Bay $\left(22^{\circ} 41^{\prime}-22^{\circ} 56^{\prime} \mathrm{S}\right.$ and $43^{\circ} 02^{\prime}$ $43^{\circ} 18^{\prime} \mathrm{W}$ ) is one of the largest coastal bays in Brazil. It is a eutrophic, polluted system, mainly impacted by untreated domestic runoff from the 8 million inhabitants of its basin (JICA, 1994). This shallow bay measures $30 \mathrm{~km}$ from south to north, with a $131 \mathrm{~km}$ perimeter, surface area of $384 \mathrm{~km}^{2}$, and a water volume of $1.87 \times 10^{9} \mathrm{~m}^{3}$. The local climate is humid tropical, with warm wet summer and cool dry winter. Mean air temperature is $23.7^{\circ} \mathrm{C}$, and the mean relative humidity is $78 \%$. Tides in the bay are mixed, mainly semidiurnal, with amplitudes ranging from $0.3 \mathrm{~m}$ to $1.0 \mathrm{~m}$ (Kjerfve et al., 2001). Previous studies (Mayr et al., 1989) have shown that Guanabara Bay can be divided into different regions. Near to the bay entrance, hydrobiological characteristics are under the influence of tropical coastal waters. This is the richest area in terms of zooplankton density and diversity, and most of the tropical coastal groups are found there. In the inner part of the bay, which is highly polluted, almost none of the main zooplankton groups persist (Valentin et al., 1999). The spatial distribution of cladocerans in Guanabara Bay follows this same pattern (Marazzo and Valentin, 2001).

\section{METHODS}

\section{Sampling Procedure}

The sampling station was located near the entrance of the bay where the water depth is about $30 \mathrm{~m}$. This location was selected on the basis of preliminary observations of the spatial variability of zooplankton. The station was previously defined as a hydrologically homogeneous area by Mayr et al. (1989).

Data on temperature, salinity and zooplankton samples were taken from surface waters at the same time (9 - 10 a.m.), every 3 - 4 days from February 2 through August 1, 2000. This sampling interval corresponds to the embryonic development time for podonids at $23{ }^{\circ} \mathrm{C}$ (see Fofonoff, 1994; Egloff et al., 1997). Samples were collected in the morning for sampling young individuals, which were released from their parents at dawn. Triplicate zooplankton samples were taken by horizontal hauls at the surface with a conical net $(200 \mu \mathrm{m}$ mesh, $0.5 \mathrm{~m}$ diameter, $2 \mathrm{~m}$ long) provided with a flowmeter. About $30 \mathrm{~m}^{3}$ of water were filtered by the net. The $200 \mu \mathrm{m}$ mesh net allowed to capture small young individuals (about $300 \mu \mathrm{m}$ size). Samples were preserved in a chilled sugar- buffered $4 \%$ formaldehyde solution, to prevent egg loss (Onbé, 1978).

In the laboratory, individuals of $P$. tergestina (young, gamogenic and parthenogenic adults) were counted from subsamples, obtained with a Folsom splitter if necessary. The subsamples were never less than $1 / 8$ of the total sample. At least 30 specimens were randomly taken from each sample (when in sufficient number) and cleared in glycerin droplets for 24 hours, after which their sex and brood size were determined and their body length (from anterior part of the head until final limit of the caudal furca) measured. Those with approximately $300 \mu \mathrm{m}$ in length, were considered as young.

\section{Calculation of Population Parameters}

Recruitment from parthenogenic eggs in zooplankton was estimated from the model of Edmondson (1968) and Paloheimo (1974), which yielded an estimate for the instantaneous per capita birth rate $b$,

$$
b=\ln ((\mathrm{E} / \mathrm{N})+1) / \mathrm{D}
$$


where $\mathrm{E}=$ number of eggs or embryos per unit volume and $\mathrm{N}=$ the population size per unit volume. $\mathrm{D}=$ egg development time (in days). In the present study, D was estimated by the seconddegree logarithmic polynomial of Bottrell (1975) based on water temperature $\left(\mathrm{T}^{\circ} \mathrm{C}\right)$.

$$
\log \mathrm{D}=0.847(\log \mathrm{T})^{2}-3.609 \log \mathrm{T}+3.796
$$

The instantaneous per capita rates of population change $r$ and death rate $d$ are calculated in combination with $b$. The rate of increase $(r)$ is calculated from successive pairs of population density values on the basis of the equation:

$$
r=\left(\ln \mathrm{Nt}_{2}-\ln \mathrm{Nt}_{1}\right) / \Delta \mathrm{t}
$$

where $\mathrm{Nt}_{1}$ and $\mathrm{Nt}_{2}$ are the population densities at times $t_{1}$ and $t_{2}$, respectively. The value of $r$ could be positive, negative, or zero depending on the change in population density during the period $\Delta t$ between two sampling occasions. The instantaneous death rate is calculated from the equation:

$$
d=b-r
$$

Death rate $(d)$ considered the sum of output effects: natural and by-predation death, plus output by water transport.

\section{RESULTS}

\section{Temperature and Salinity}

The variations in water temperature closely followed the seasons (Fig. 1). The highest temperatures $\left(25-27{ }^{\circ} \mathrm{C}\right)$ were recorded in February - April and the lowest $\left(21-22^{\circ} \mathrm{C}\right)$ in July. Anomalous low temperatures observed during summer $\left(<23{ }^{\circ} \mathrm{C}\right.$ on February 18 and March $13-$ 17 , with a minimum of $21^{\circ} \mathrm{C}$ ) were caused by the passage of cold fronts. Variations in salinity reflected the rainy season (rainfall $=191.2 \mathrm{~mm}$ from February through April, with salinity values < 34) and the dry season (rainfall=91.7 $\mathrm{mm}$ from May through July, with salinity values $>34)$. Lower salinities $(<30$, minimum 22$)$ were a consequence of heavy rains during the passage of cold fronts.

\section{TEMPERATURE}

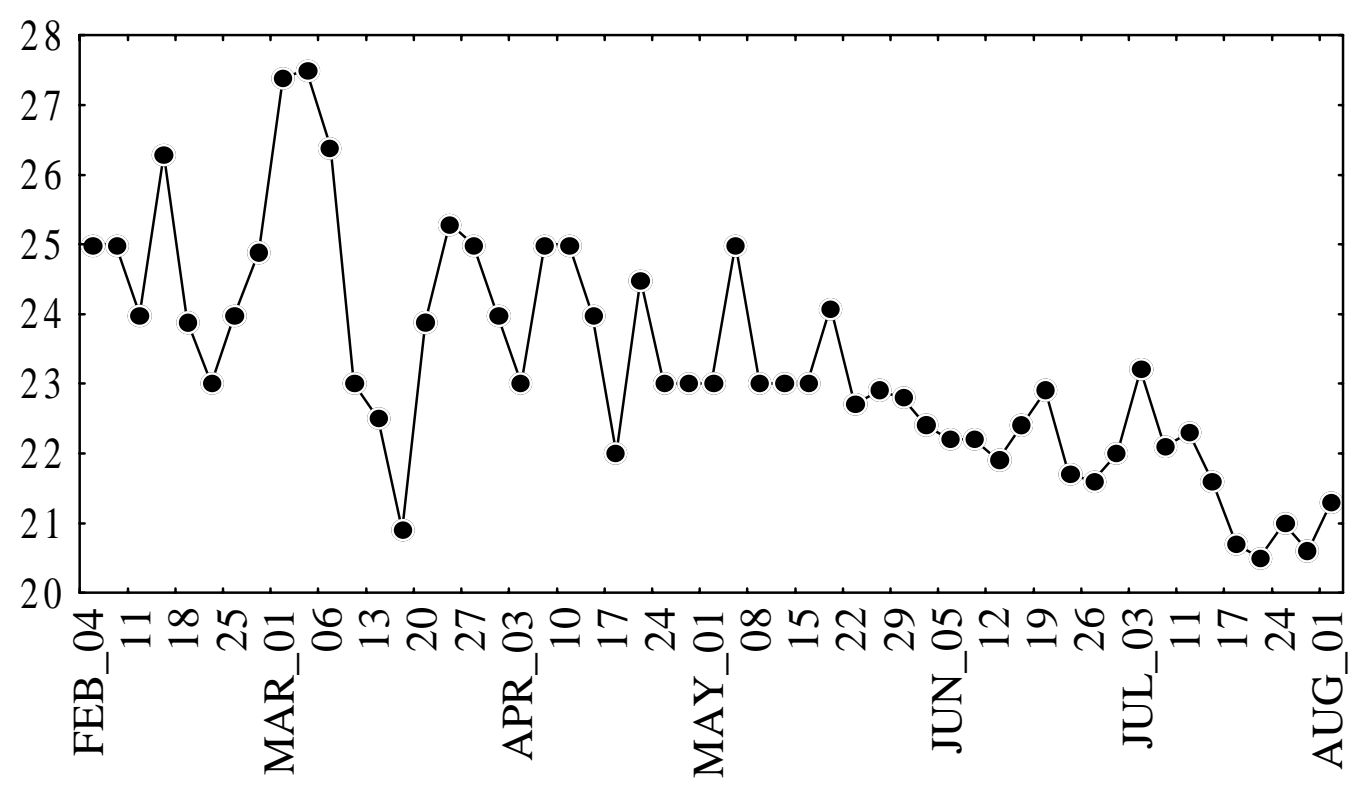




\section{SALINITY}

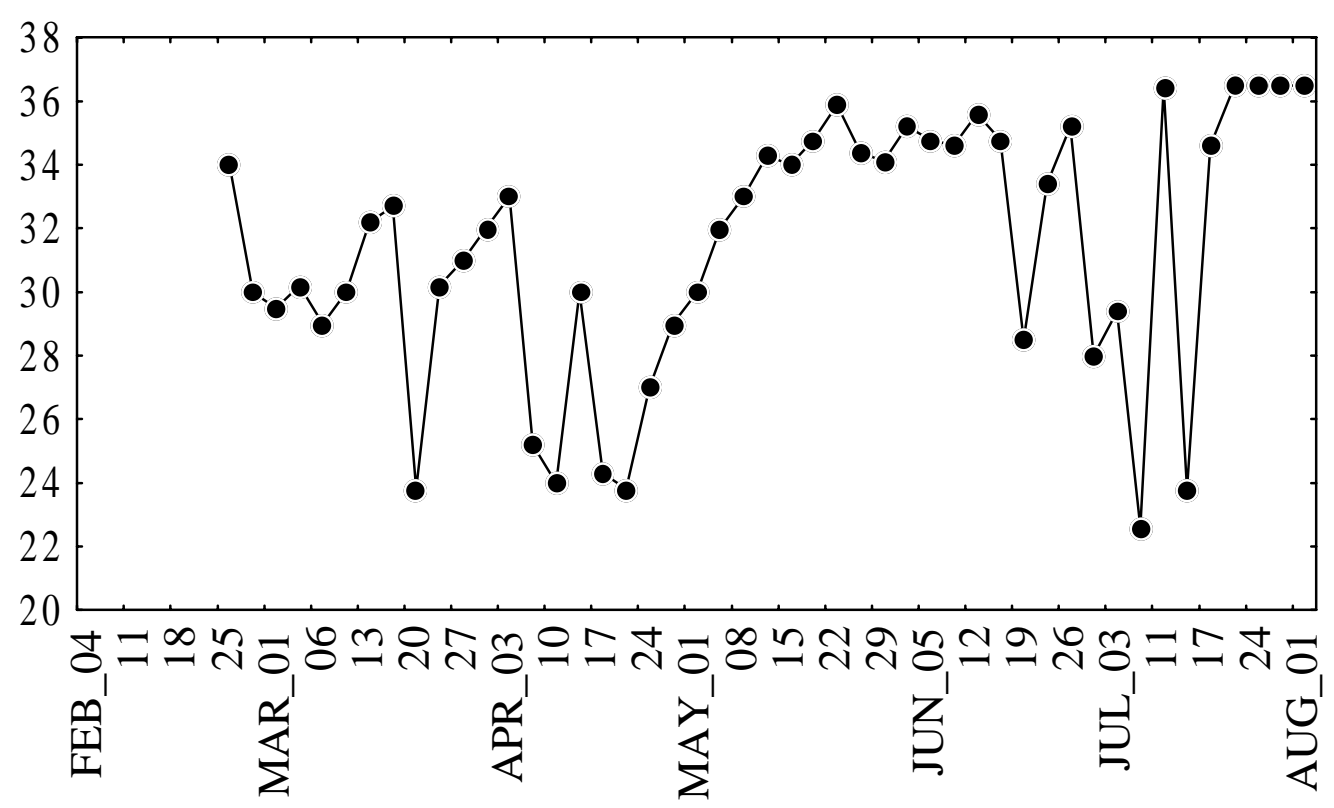

Figure 1 - Temperature $\left({ }^{\circ} \mathrm{C}\right)$ and salinity of surface water at a fixed station in the Guanabara bay.

Predators (Fig. 2)

From February to March, fish larvae showed densities frequently higher than 10 ind. $\mathrm{m}^{-3}$ (max. 30 ind. $m^{-3}$ on February 11), similar to previous records (Valentin et al., 1999). Chaetognaths (Sagitta tenuis and S. enflata) were the most abundant predators from April-August, when the salinities values were highest. Their densities exceeded 100 ind. $\mathrm{m}^{-3}$ in April 20, June 29, and July 28. Polychaetes showed sporadic density peaks of 68 (July 28), 38 (June 29), and 24 (April 3) ind. $\mathrm{m}^{-3}$.

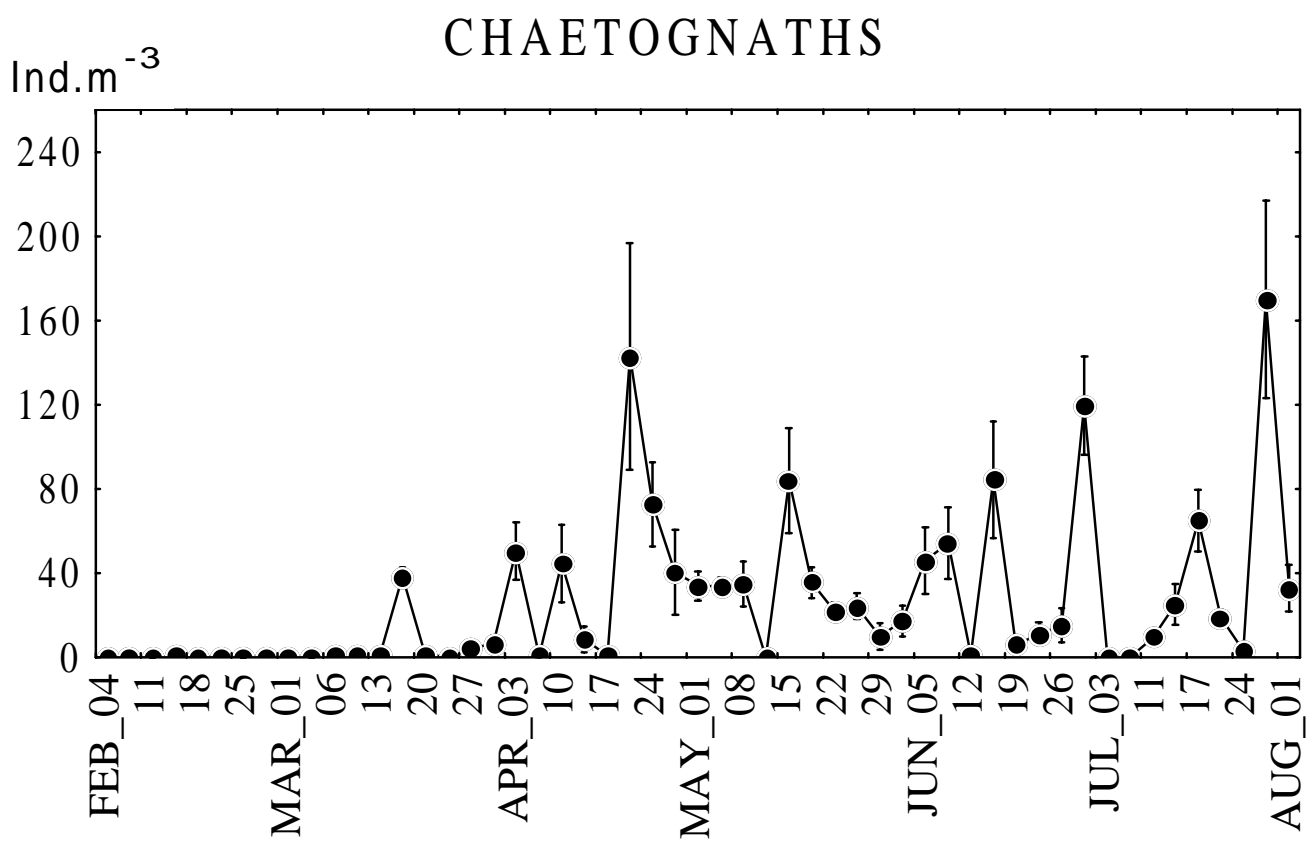



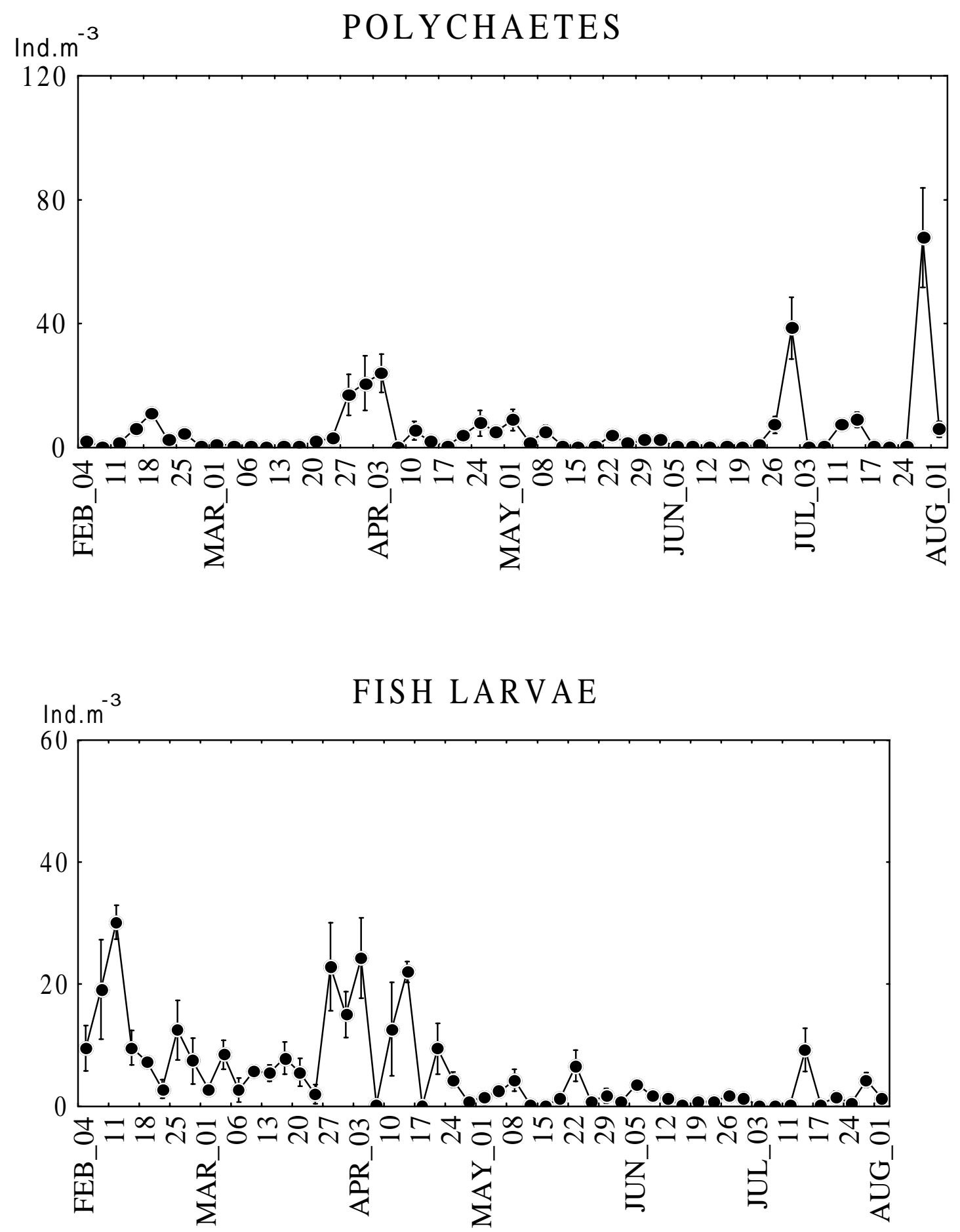

Figure 2 - Densities (ind. $\mathrm{m}^{-3}$ ) of chaetognaths, polychaetes and fish larvae at a station of Guanabara bay. Data obtained from three replicates ( solid circle $=$ mean; vertical bar $=$ one standard deviation) 
Density of Pseudevadne tergestina (Fig. 3)

$P$. tergestina occurred in Guanabara Bay from February until July. However, its highest population densities were observed only in March (Max. $603 \pm 60$ ind. $\mathrm{m}^{-3}$ ). Densities in other months were always $<20$ ind. $\mathrm{m}^{-3}$. During the period of study, the percentage of young animals varied widely. Successive peaks $(20-30 \%)$ were separated by low percentages $(<10-15 \%)$. The mean body lengths of adults ranged from 550 $650 \mu \mathrm{m}$ in February - March. The lowest mean body lengths $(400 \mu \mathrm{m})$ were registered at the end of the period of occurrence of planktonic individuals.

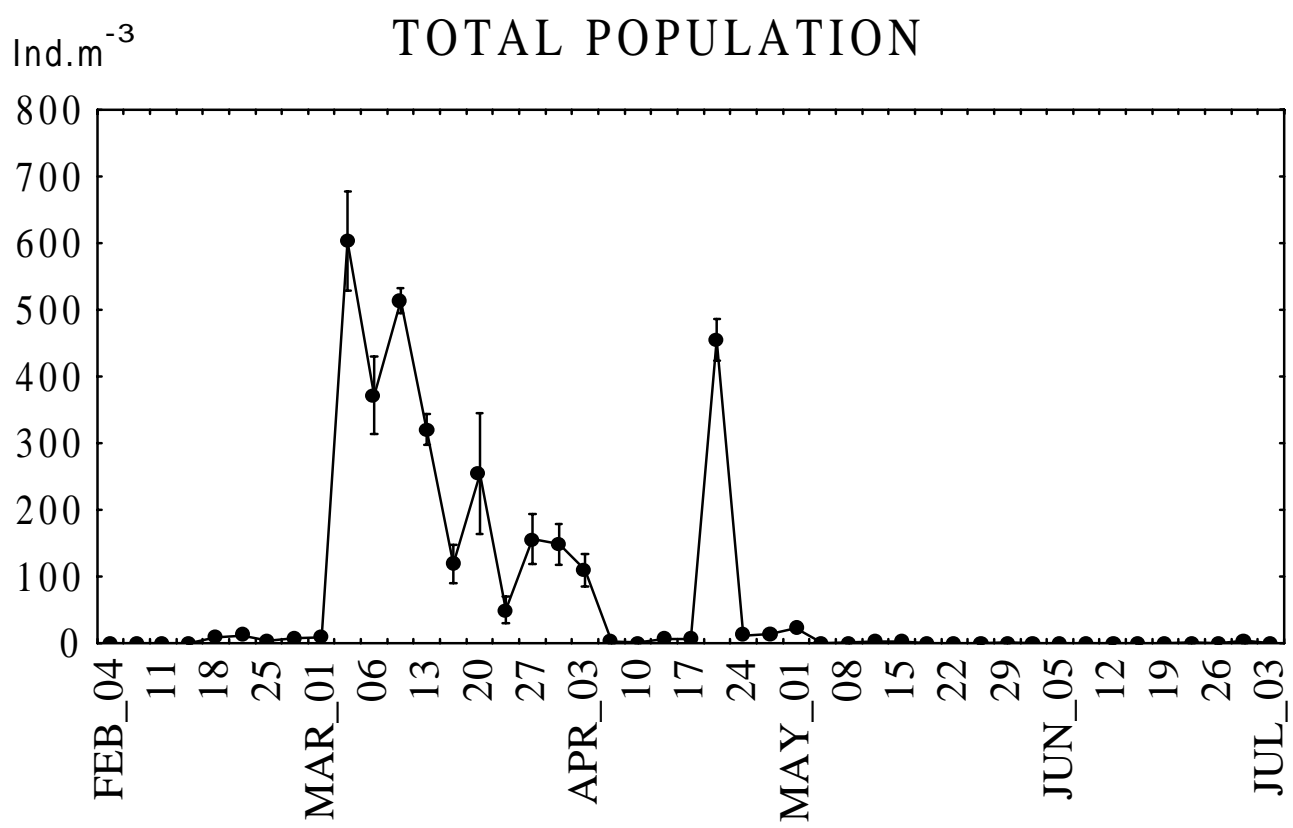

$\% \quad$ YOUNG INDIVIDUALS

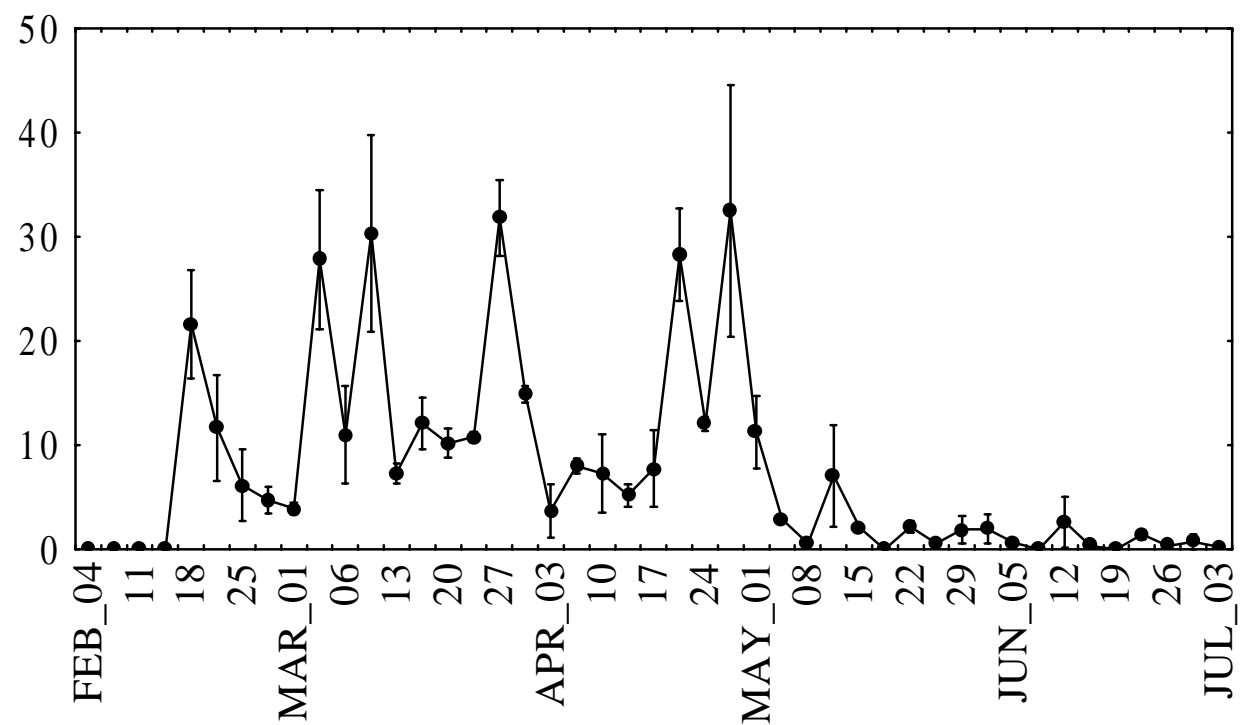



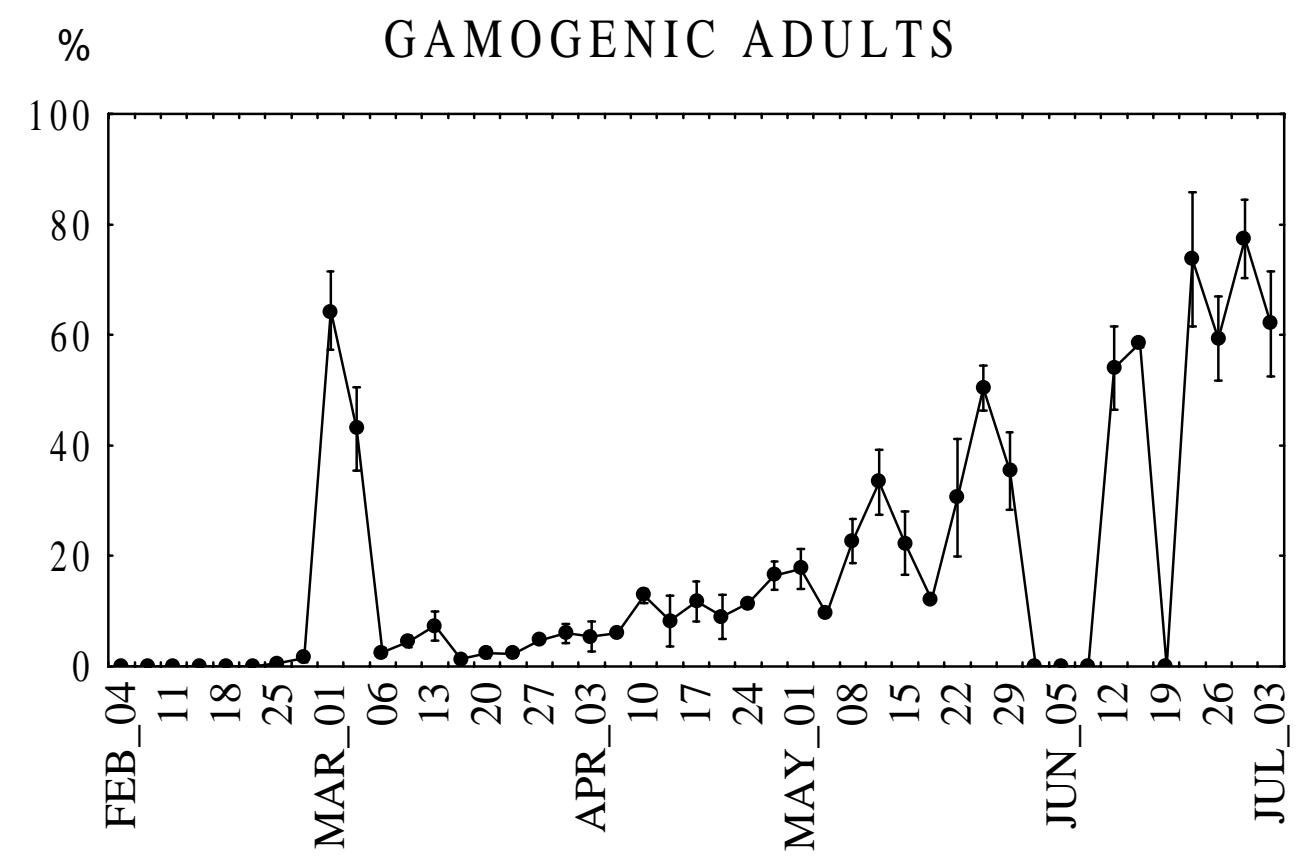

Figure 3 - Total densities (ind. $\mathrm{m}^{-3}$ ) of $P$. tergestina, and percentage of young and gamogenic individuals, at a fixed station in the Guanabara Bay. Data obtained from three replicates (solid circle $=$ mean; vertical bar $=$ one standard deviation)

In February and March, the population of adult $P$. tergestina included fewer than $7 \%$ gamogenic animals. From then on the percentage steadily increased to more than $70 \%$ in June and July.

There was evidence of intense gamogenic reproduction during that period, when the planktonic samples contained resting eggs of $P$. tergestina at densities of 1 egg. $\mathrm{m}^{-3}$. The ratio of males to females carrying resting eggs was approximately $1 / 1.8$.

\section{BIRTH RATE}

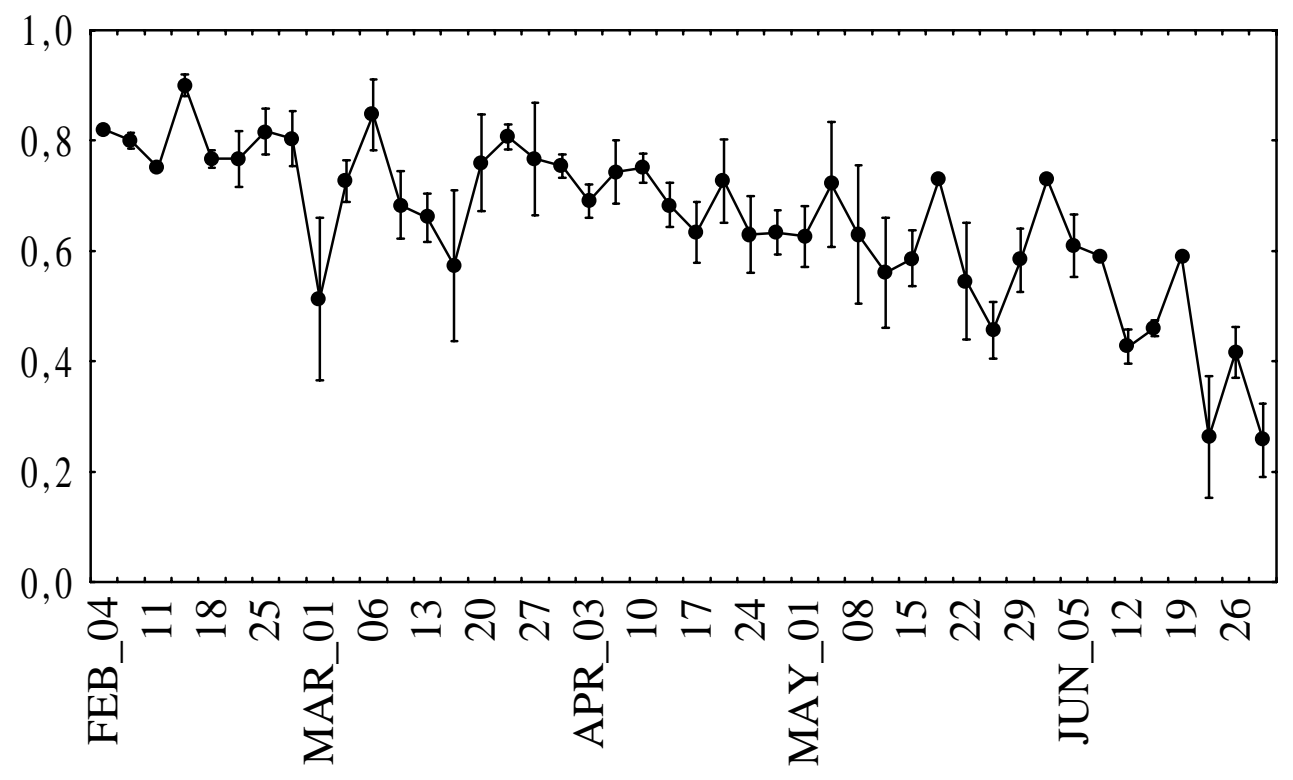




\section{GROWTH RATE}

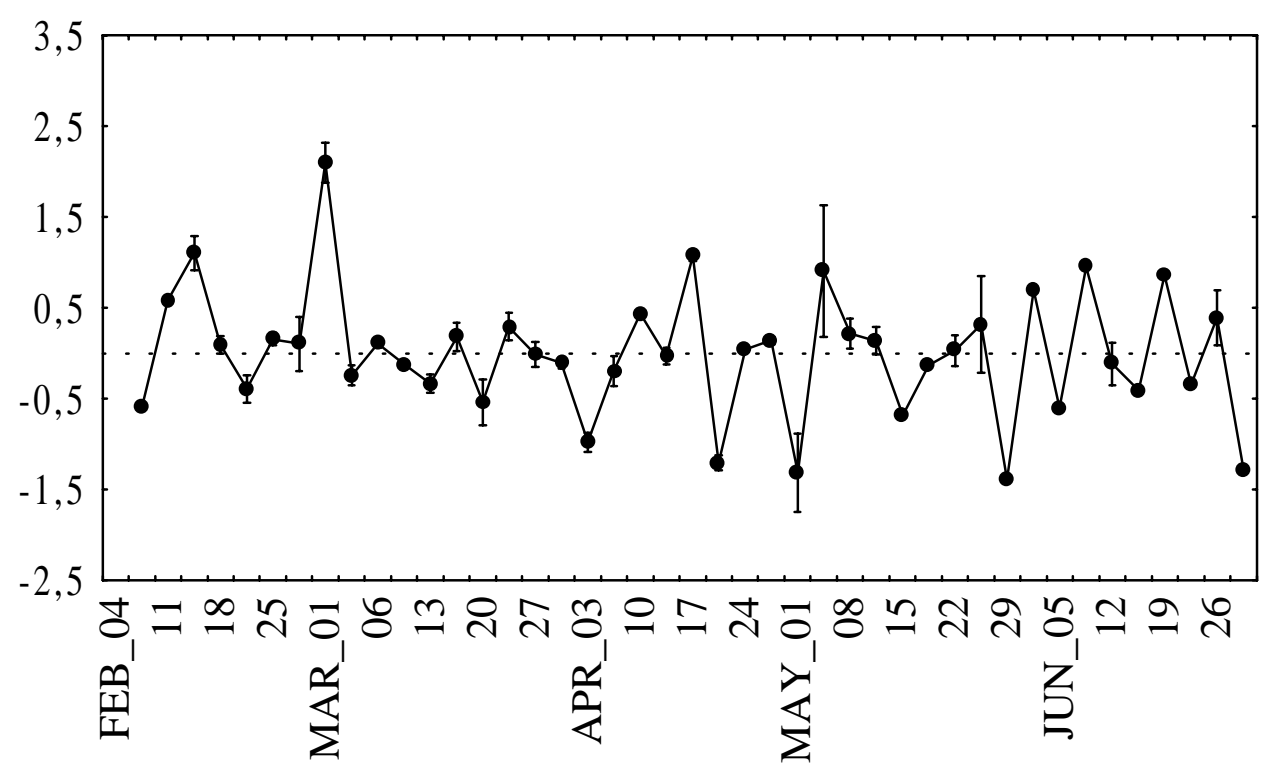

DEATH RATE

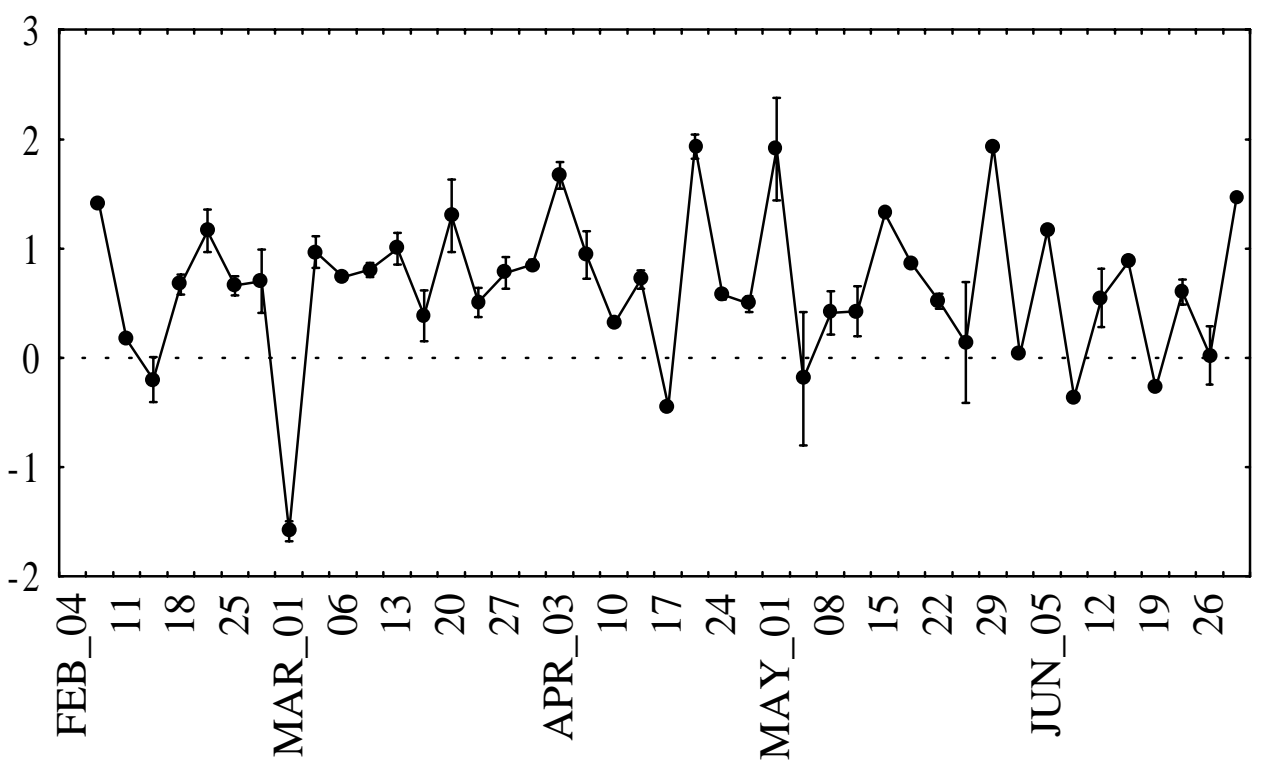

Figure 4 - Birth, growth and death rates of P. tergestina, in a station of Guanabara bay. Data obtained from three replicates (solid circle $=$ mean; vertical bar $=$ one standard deviation.).

Parameters of the Pseudevadne tergestina population

Fecundity of parthenogenic females (mean number of embryos per female) varied from 4.6 to $8.0 \mathrm{emb}$. female ${ }^{-1}$ (mean $6.36 \pm 0.77 \mathrm{emb}$. female $^{-1}$ ).
The highest fecundity ( 7 - 8 emb. female $\left.{ }^{-1}\right)$ occurred in February through mid-March, after which fecundity decreased to a minimum of $4-5$ emb. female ${ }^{-1}$ at the end of the study period. 
There was little variation in the development time (D) of embryos: from 2.27 to 3.28 days (mean $=$ $2.81 \pm 0.25$ days). Knowledge of $\mathrm{D}$ allowed us to calculate the birth rate (b), which varied from 0.90 ind..$^{-1}$.day ${ }^{-1}$ on February 14 to 0.25 ind $^{-1}$.day ${ }^{-1}$ on June 29 (mean $0.65 \pm 0.14$ ind. $^{-1}$.day ${ }^{-1}$ ) (Fig. 4). The birth rate declined during the study period. The instantaneous population growth rate $(r)$ ranged from -1.30 to 2.09 day $^{-1}$. However, many of the samples had values near 0 (zero), and high negative values occurred principally from April onwards (Fig. 5). The instantaneous death rate showed a similar but inverse pattern, with values varying from -1.6 to 1.9 day $^{-1}$ (Fig. 4).

\section{DISCUSSION}

Although Guanabara Bay can be considered as polluted system, populations of $P$. tergestina can still have conditions for development. This cladoceran occurs where habitat conditions are most characteristic of embayments and may be used as an indicator species of the coastal warm water mass (Onbé, 1999). In agreement with Marazzo and Valentin (2001), the results of this study showed that $P$. tergestina occurs in Guanabara Bay during the entire spring-summer period. The population declined drastically in abundance from April to July, after which no individual was detected in samples. Such a biological cycle, restricted mainly to summer, is characteristic of $P$. tergestina, as has been observed in other parts of the world (Egloff et al., 1997). This species reaches its maximum populations in the plankton of the Inland Sea of Japan during the warmer season (temperature $>22$ $\left.{ }^{\circ} \mathrm{C}\right)$. It was termed a "warm water form" by Onbé (1974), who considered temperature as the most important environmental factor controlling the seasonal distribution of each species of cladoceran. The factors leading to the appearance of $P$. tergestina at the beginning of spring-summer in Guanabara Bay are still hypothetical. Although temperature does not vary much seasonally in this tropical region $\left(21-27^{\circ} \mathrm{C}\right)$, the disappearance of $P$. tergestina during the winter led us to consider temperature as the determinant factor governing its population dynamics in Guanabara Bay, in the same way as observed in temperate regions. In fact, there was a positive correlation between temperature and birth rate $(\mathrm{r}=0.58, \mathrm{p}=0.05)$, which was correlated, as expected, positively with fecundity $(\mathrm{r}=0.64, \mathrm{p}=0.05)$ and body length $(\mathrm{r}=0.36, \mathrm{p}=0.05)$, and strongly negatively with the percentage of gamogenic individuals $(\mathrm{r}=-0.83, \mathrm{p}=0.05)$. Thus, the temperature increase in summer could be partly responsible for the increase in fecundity and birth of $P$. tergestina in Guanabara Bay.

Another factor possibly responsible for the beginning of the planktonic $P$. tergestina population could be the hatching of resting eggs as a "seed" source of embryos. The observed variation of resting eggs in the sediment of Guanabara Bay over time seemed to support this hypothesis. Barros et al. (2000) observed a succession of maximum and minimum densities of resting eggs at the sampling location in the bay which probably resulted from periodic hatching. Resting eggs hatch in pulses at certain times, rather than continuously (Valentin and Marazzo, 2003). The factors responsible for initiating hatching are presently unknown. Salinity as well as temperature and the duration of the darkincubation period may be stimulating factors (Egloff et al., 1997).

The peaks in $P$. tergestina density observed in Guanabara Bay were much lower than densities reported from other locations, e.g., 5000 ind. $\mathrm{m}^{-3}$ reported in the Inland Sea of Japan (Onbé, 1985). These low densities seem to be a common pattern of cladoceran distribution in Guanabara Bay (Marazzo and Valentin, 2001 for Penilia avirostris). The mean growth rate $\left(0.50 \pm 0.50 \mathrm{day}^{-1}\right.$, excluding negative values), yielding a doubling time of 2 days, was coherent with the low population density. One reason for this low mean growth rate during summer could be: a possible influence of pollution from the internal water of the bay, which tended to increase during this period.

Trophic factors must also be considered in explaining this low population growth. Guanabara Bay is highly eutrophic, with high primary biomass (> $50 \mu \mathrm{g}$ chlorophyll per litre; Valentin et al., 1999); thus the availability of food could probably not be a limiting factor for growth of $P$. tergestina. On the other hand this cladoceran species could suffer high predation pressure by chaetognaths, whose densities are positively correlated with the $P$. tergestina death rate $(r=0.36, p=0.05)$ and negatively with its growth rate $(\mathrm{r}=-0.42, \mathrm{p}=0.05)$, and by polychaetes, whose densities were negatively correlated with its growth rate $(\mathrm{r}=-0.37, \mathrm{p}=0.05)$. 
The collapse of the population was due not only to the direct effect of predation and temperature, but also to the switch within the population itself from parthenogenic to sexual reproduction (without parthenogenic individuals producing more offspring, the population cannot sustain itself). Causes of the switch of population from parthenogenic to gamogenic reproduction are still unknown. Hypothesis on effect of unfavourable environmental conditions, such as low temperature, salinity or dissolved oxygen, have been proposed (Egloff, et al., 1997; Onbé, 1999). Physical transport of water by horizontal advection might also explain the density variations of $P$. tergestina, with their sharp decreases and high death rates on certain occasions. According to Kjerfve et al. (1997), tidal currents are strongest at the mouth of the bay (mean velocity of $0.75 \mathrm{~m}^{-1} \mathrm{~s}^{-1}$ ). Thus, water displacement during flood or ebb tide could be estimated at about $7 \mathrm{~km}$, which is the limit where Valentin et al., (1999) observed a maximum of $33 \%$ reduction of mesozooplankton density. Contribution of this factor to the decrease of $P$. tergestina probably affected the parameter $d$ on 1-3 March, 20 April, 1 May and 29 June, when low salinities $(<30)$ were recorded (in consequence of the outflow from the inner part of the bay).

\section{CONCLUSIONS}

- Pseudevadne tergestina population occurs in Guanabara Bay during the entire spring-summer period.

- Start of P. tergestina population in Guanabara Bay is caused by the increase of temperature in spring-summer, which is partly responsible for the increase in fecundity and birth of $P$. tergestina population and also for the hatching of resting eggs.

- Predation pressure, temperature decrease and switch from parthenogenic to gamogenic reproduction control the population density, and affect the fall-winter population collapse.

- Horizontal transport of water by tidal currents contributes partially to the reduction of population density.

- Further research on P. tergestina in Guanabara Bay would be necessary for better understanding of the ecology of this cladoceran in tropical embayment systems.

\section{ACKNOWLEDGEMENTS}

This study was supported by the Conselho Nacional de Desenvolvimento Científico e Tecnológico $(\mathrm{CNPq})$, the Fundação de Amparo à Pesquisa no Estado do Rio de Janeiro (FAPERJ), and the Programa de Apoio a Núcleos de Excelência (PRONEX).

\section{RESUMO}

A variação temporal de densidade e dos parâmetros populacionais de Pseudevadne tergestina foi estudada na Baía de Guanabara. As coletas foram realizadas na superfície de uma estação fixa, a cada 3-4 dias, de fevereiro a agosto de 2000. Os máximos de abundância dessa espécie foram observados em março, com densidades variando de 20 a 600 ind. $\mathrm{m}^{-3}$. Foram calculadas as taxas de nascimento $\left(0,25-0,90\right.$ ind.dia- $\left.{ }^{1}\right)$, de crescimento $\left(-0,30 \quad-0,90\right.$ ind.dia- $\left.{ }^{1}\right)$ e de mortalidade $\left(-1,6 \quad-1,9\right.$ dia $\left.^{-1}\right)$. O início da população pode ser atribuído ao aumento da temperatura e à eclosão dos ovos de resistências. A população entra em colapso no outono - inverno, como conseqüência dos efeitos combinados de diversos fatores: a diminuição da temperatura da água (de $27^{\circ} \mathrm{C}$ para $21^{\circ} \mathrm{C}$ ) influenciando o tempo de desenvolvimento dos ovos (de 2,27 para 3,28 dias), a predação por Chaetognatha cuja densidade alcançou 100 ind. $\mathrm{m}^{-3}$ e a mudança de estratégia reprodutiva de $P$. tergestina, de partenogênica para gametogênica. $O$ transporte das águas pelas correntes contribui também na redução da densidade populacional dessa espécie.

\section{REFERENCES}

Alecrim, V. P. (2000), Cladocera (Crustacea, Branchiopoda) na Baía de Guanabara (RJ, Brasil). Monografia (Bacharelado em Biologia Marinha), Universidade Federal do Rio de Janeiro.

Barros, S. S.; Alecrim, V. P.; Marazzo, A. and Valentin, J. L. (2000), Resting eggs of cladocerans in the Guanabara bay: horizontal, vertical and temporal distribution. Nauplius, 8, 237-244.

Bottrell, H. H. (1975), The relationship between temperature and duration of egg development in some epiphytic Cladocera and Copepoda from the River Thames. Oecologia, 18, 63-84. 
Edmondson, W. T. (1968), A graphical model for evaluating the use of the egg ratio for measuring birth and death rates. Oecologia, 1, 1-37.

Egloff, D. A.; Fofonoff, P. W. and Onbé, T. (1997), Reproductive biology of marine cladocerans. In: Blaxter, J. H. S. and Southward, A. J. (Eds.). Advances in Marine Biology. Academic Press. pp. 79-167.

Eriksson, S. (1974), The occurrence of marine Cladocera on the west coast of Sweden. Marine Biology, 26, 319-327.

Fofonoff, P. W. (1994), Marine Cladocerans in Narragansett Bay. PhD Thesis, University of Rhode Island, Kingston, USA.

JICA (1994), The Study on Recuperation of the Guanabara Bay Ecosystems. Report. Japan International Cooperation Agency. Kokusai Kogyo Co., Ltd., Tokyo.

Kjerfve, B.; Ribeiro, C. H. A.; Dias, G. T. M.; Filippo, A. M. and Quaresma, D V. S. (1997), Oceanographic characteristics of an impacted coastal bay: Baía de Guanabara, Rio de Janeiro, Brazil. Continental Shelf Research, 17, 1609-1643.

Kjerfve, B.; Lacerda, L. D. and Dias, G. T. M. (2001), Baía de Guanabara, Rio de Janeiro, Brazil. In: Seeliger, U. and Kjerfve, B. (Eds.). Coastal Marine Ecosystems of Latin America. Springer-Verlag, Berlin, Heidelberg. pp. 107-117.

Marazzo, A. and Valentin, J. L. (2000), Daily variation of marine cladoceran densities in a tropical bay. Hydrobiologia, 428, 205-208.

Marazzo, A. and Valentin, J. L. (2001), Spatial and temporal variations of Penilia avirostris and Evadne tergestina (Crustacea, Branchiopoda) in a tropical bay, Brazil. Hydrobiologia, 445, 133-139.

Mayr, L. M.; Tenembaum, D. R.; Villac, M. C.; Paranhos, R.; Nogueira, C. R.; Bonecker, S. L. C. and Bonecker, A. C. T. (1989), Hydrobiological characterization of Guanabara Bay. In: Magoon, O. and Neves, C. (Eds.). Coastlines of Brazil. New York : American Society of Civil Engineers. pp. 124-138.

Onbé, T. (1974), Studies on the ecology of marine cladocerans. Journal of the Faculty of Fisheries and Animal Husbandry, 13, 83-179.

Onbé, T. (1978), Sugar flotation method for sorting the resting eggs of marine cladocerans and copepods from sea-bottom sediment. Bulletin of the Japanese Society of Scientific Fisheries, 44, 1411.

Onbé, T. (1985), Seasonal fluctuations in the abundance of populations of marine cladocerans and their resting eggs in the Inland Sea of Japan. Marine Biology, 87, 83-88.

Onbé, T. (1999), Ctenopoda and Onychopoda (=Cladocera). In: Boltovskoy, D. (Eds.). South Atlantic Zooplankton. Brachuys Publishers, Leiden, pp. 797-811.

Paloheimo, J. E. (1974), Calculation of instantaneous birth rate. Limnology and Oceanography, 19, 692-694.

Resgalla Jr., C. and Montu, M. (1993), Cladóceros marinhos da plataforma continental do Rio Grande do Sul - Brasil. Nauplius, 1, 63-79.
Thiriot, A. (1972), Les Cladocères de Méditerranée occidentale III. Cycle et répartition à Banyuls-surMer (Golfe du Lion). Synthèse des années 19651969. Vie et Milieu, 23, 243-295.

Uye, S. (1982), Seasonal cycles in abundance of major holoplankton in the innermost part of Onagawa Bay, Northeast Japan. Journal of the Faculty of Applied Biological Science, 21, 1-10.

Valentin, J. L. and Marazzo, A. (2003), Modelling of the population dynamics of Penilia avirostris (Branchiopoda, Ctenopoda) in a tropical bay. Acta Oecologica, 24, S369-S376.

Valentin, J. L.; Monteiro-Ribas, W. M.; Mureb, M. A. and Pessotti, D. E. (1987), Sur quelques zooplanctontes abondants dans l' upwelling de Cabo Frio (Brésil). Journal of Plankton Research, 9, 1195-1216.

Valentin, J. L.; Tenembaum, D. R.; Bonecker, A. C. T.; Bonecker, S. L. C.; Nogueira, C. R. and Villac, M. C. (1999), O sistema planctônico da baía de Guanabara: síntese do conhecimento. In: Silva, S. H. G. and Lavrado, H. P. (Eds.). Ecologia dos Ambientes Costeiros do Estado do Rio de Janeiro. Série Oecologia Brasiliensis, vol. VII, Programa de PósGraduação em Ecologia, Universidade Federal do Rio de Janeiro, Brasil, pp. 35-59.

Vourinen, I. and Ranta, E. (1987), Dynamics of marine meso-zooplankton at Seili, Northern Baltic Sea, in 1967-1975. Ophelia, 28, 31-48.

Received: January 22, 2003; Revised: July 02, 2003; Accepted: January 29, 2004. 